\title{
Pendidikan Alternatif dengan Model Pesantren Salafi-Khalafi (Studi Komplek Rz Pondok Pesantren Al Munawwir Krapyak Yogyakarta)
}

\author{
Lita Nala Fadhila \\ Universitas Negeri Sebelas Maret Surakarta \\ e-mail: litanala@gmail.com
}

\begin{abstract}
Islamic boarding school (pesantren) is regarded as an alternative education in the midst of formal education's weaknesses that is regulated by the government. In its growth to become an alternative education, the model of salafi (traditional) pesantren has been criticised for its identity loss when it is compromised with a matter called modernity. To answer the criticism addressed to pesantren as an alternative education, complex $R 2$ Pondok Pesantren (Islamic boarding house) al Munawwir Krapyak Yogyakarta build a pesantren education based on salafi-khalafi (traditional-modern) model. This research focuses on pesantren education based on salafi-khalafi model which is built in Complex $R 2$ that applies pesantren education consisting of basic values, boarding house, curriculum, and the used learning methods. The education built in complex $R 2$ becomes an alternative choice for people who want to get an education based on salafi and khalafi pesantren model at the similar time.Islamic boarding school (pesantren) is regarded as an alternative education in the midst of formal education's weaknesses that is regulated by the government because it is able to provide an education for any circles of society and it is oriented toward scientific development, intellectual aptitude, and moral building.
\end{abstract}

Keywords: Pesantren, Alternative Education, Salafi-Khalafi. 


\section{Pendahuluan}

Pesantren merupakan lembaga pendidikan agama Islam yang memiliki sejarah panjang dalam dunia pendidikan di Indonesia.Nurcholish Madjid mengatakan dari segi historis pesantren tidak hanya identik dengan makna keislaman, tetapi juga mengandung makna keaslian (indigenous) Indonesia (Madjid, 1993: 224). Sebagai lembaga pendidikan agama Islam khas Indonesia, pesantren dilihat sebagai pendidikan alternatif di tengah kelemahan pendidikan formal yang dikelola oleh pemerintah (Madjid, 1993: 222) karena pesantren mampu menyediakan pendidikan bagi semua kalangan dan berorientasi terhadap pengembangan keilmuan, kecerdasan intelektual dan persemaian akhlak.

Dalam perkembangannya menjadi pendidikan alternatif, sistem pendidikan pesantren salafi (tradisional) yang hanya mempelajari ilmu agama dinilai belum bisa menjawab tantangan perubahan zaman. Di sisi lain, pesantren khalafi (modern) yang berdiri sebagai jawaban atas tantangan dari dalam maupun dari luar pesantren dinilai telah kehilangan pendidikan khas pesantren. Pertanyaan yang kemudian diajukan adalah model pesantren seperti apa yang bisa dijadikan pendidikan alternatif di tengah-tengah sistem pendidikan di Indonesia? Berangkat dari pertanyaan di atas, peneliti mengadakan penelitian mengenai pesantren yang sedang berada di dua arus-yang salafi dan khalafi, yang tradisional dan modern.

Penelitian ini dilakukan di salah satu pesantren yang menjadi contoh kajian variasi pendidikan alternatif model pesantren salafi-khalafi, yaitu Komplek R2 Pondok Pesantren Al-Munawwir Krapyak Yogyakarta.

\section{Hakikat Pendidikan}

Ki Hajar Dewantara merumuskan konsep mengenai pendidikan, yaitu upaya memanusiakan manusia secara manusiawi. Anak didik seharusnya dibimbing sesuai kodrat alamnya (Saksono, 2008: 48). Pendidikan menurut Ki Hajar Dewantara merupakan proses kebudayaan yang utuh. Pendidikan tidak hanya berurusan dengan pengajaran saja, tetapi juga berurusan dengan bakat, psikologi, karakter, dan moral. 
Pendidikan tidak terbatas pada ruang formal dan nonformal melainkan meliputi seluruh kehidupan di alam semesta (Saksono, 2008: 50).

Hakikat pendidikan dilihat dari sudut pandang sosiologis salah satunya adalah konsiensialisme yang diperkenalkan oleh Paulo Freire. Konsiensialisme atau pendidikan pembebasan melihat bahwa hakikat pendidikan sebagai pembebasan manusia dari berbagai penindasan yang bertujuan untuk membangkitkan kesadaran manusia bahwa manusia mempunyai martabat dan kebebasan. Kesadaran yang diharapkan adalah kesadaran untuk menghidupkan suatu masyarakat yang lebih demokratis atau masyarakat madani (Tilaar, 2002:26).

Pendidikan seringkali dikaitkan dengan konsep sekolah. Sekolah adalah sebuah lembaga pendidikan di mana para guru dan para murid berinteraksi pada tata cara yang ditetapkan (Knight, 2007: 14). Sekolah sebenarnya hanya menjadi salah satu agen masyarakat untuk kegiatan belajar dan pendidikan (Knight, 2007: 18). Tetapi yang terjadi kemudian sekolah menjadi keharusan, tempat belajar yang mendapat legitimasi penuh dari masyarakat. Begitu berartinya sekolah bagi masyarakat sehingga sukses tidaknya seseorang sangat tergantung dari seberapa tinggi tingkat pendidikan yang telah dicapai. Kondisi inilah yang membuat Ivan Illich berfikir mengenai konsep bebas dari sekolah. Illich menyadari bahwa bagi sebagian besar manusia, hak belajar mereka dipersempit menjadi kewajiban sekolah.

Kritik Illich terhadap sistem sekolah adalah pemahaman masyarakat yang kabur mengenai proses dan inti pengetahuan. Imajinasi murid dilatih untuk menerima jasa — sesuatu yang diukur berdasarkan untung-rugi-bukan nilai, hal yang menjadi prinsip hidup manusia (Saksono, 2008: 18). Seharusnya hakikat sekolah menurut Fraenkel merupakan tempat persemaian nilai seperti yang dikutip dari Azra, "sekolah, pada hakikatnya bukanlah sekedar tempat transfer of knowledge belaka. Sekolah tidaklah semata-mata tempat dimana guru menyampaikan pengetahuan melalui berbagai mata pelajaran. Sekolah juga adalah lembaga yang menguasahakan usaha dan proses pembelajaran yang berorientasi pada nilai (value oriented enterprise)" (Azra, 2002: 76).

At.t Volume. 2, No. 1, Januari-Juni 2017 


\section{Pendidikan Alternatif}

Kompleksitas masalah pendidikan dan sekolah dewasa ini, memunculkan ideide mengenai pendidikan alternatif. Menurut Yusufhadi Miarso, pendidikan alternatif merupakan istilah generik yang meliputi sejumlah besar program atau cara pemberdayaan peserta didik yang dilakukan berbeda dengan cara tradisional (Miarso, t.th:1). Secara umum berbagai bentuk pendidikan alternatif itu mempunyai tiga kesamaan yaitu, (1) pendekatannya yang lebih bersifat individual; (2) memberikan perhatian lebih besar kepadapeserta didik, orangtua/keluarga, dan pendidik; (3) ilmu pengetahuan yang dikembangkan berdasarkan minat dan pengalaman.

Pendidikan alternatif berangkat dari semangat pandangan falsafah dan teori pendidikan dari sejumlah tokoh. Di antaranya adalah Paulo Freire, Ivan Illich, dan Ki Hajar Dewantara (Wiarso, t.th:5). Paulo Freire merupakan tokoh yang merumuskan konsep pendidikan yang membebaskan dan memerdekakan manusia dari ketertindasan (Saksono, 2008: 6). Konsep pendidikan Freire mempunyai visi filosofis yakni manusia yang terbebaskan (Freire, 2002: 12). Dialog antar-manusia harus berdasarkan terutama pada kepekaan terhadap kemampuan bawaan di dalam tiap manusia untuk menemukan dirinya sendiri (Saksono, 2008: 6).

Tawaran yang diajukan oleh Freire mengenai pendidikan adalah problem posing education, menghadapkan pada masalah pendidikan (Freire, 2002: xv). Pendidikan ini melihat guru dan murid adalah subyek yang sama-sama belajar, saling memanusiakan. Pendidikan ini menciptakan hubungan dialogis antara guru-murid. Pada akhirnya pendidikan ini memberikan tantangan kepada manusia untuk membuka rahasia realita dan menuntut suatu tanggapan terhadap tantangan tersebut (Saksono, 2008: 8).

Ivan Illich, seorang pastur kelahiran Vienna yang memperkenalkan konsep bebas dari sekolah mengajukan beberapa pendapat mengenai tujuan diadakannya lembaga pendidikan. Bagi Illich, lembaga pendidikan paling tidak harus memenuhi tiga tujuan, yakni lembaga pendidikan harus (1) memberi ruang bagi semua orang yang ingin belajar untuk menggunakan sumber daya yang ada; (2) mengijinkan semua orang yang ingin membagikan apa yang mereka ketahui; (3) memberi peluang kepada semua orang yang ingin menyampaikan suatu masalah ke tengah masyarakat (Saksono, 2008: 58). 
Tawaran pendidikan alternatif juga disampaikan oleh Ki Hajar Dewantara dengan sistem amongnya. Among yang berasal dari kata Jawa mengandung arti mengabdi melalui bimbingan. Pamong atau pengampu menjadi tugas seorang guru yang mendidik sekaligus mengajar lengkap dengan teladannya (Saksono, 2008: 48). Antara konsepsi, pemikiran dan strategi pendidikan menurut Ki Hajar Dewantara dapat diwujudkan dengan sistem asrama, di mana guru dan murid tinggal di lingkungan yang sama menjadi sebuah keluarga besar. Dengan sistem asrama proses belajar-mengajar menjadi tenang dan nyaman dalam suasana penuh kekeluargaan (Saksono, 2008: 55).

\section{Pesantren}

Salah satu bentuk pendidikan alternatif di Indonesia adalah pesantren (Madjid, 1997: 46). Selo Soemardjan (2009: 404) menggambarkan keunikan pendidikan pesantren sebagai sebuah lembaga pendidikan alternatif yang terbuka bagi siapapun karena tidak ada persyaratan resmi yang diperlukan untuk menjadi seorang santri. Pesantren tidak pernah menolak siapapun yang ingin menjadi santri, asalkan santri tersebut serius belajar dan hidup dengan tradisi dan nilai-nilai pesantren.

Pesantren digunakan untuk menyebutkan jenis pendidikan agama Islam khas Indonesia. Pesantren menurut M. Arifin berarti, "Suatu lembaga pendidikan agama Islam yang tumbuh serta diakui masyarakat sekitar, dengan sistem asrama di mana santri-santri menerima pendidikan agama melalui sistem pengajianatau madrasah yang sepenuhnya berada di bawah kedaulatan dari leadership seorang atau beberapa orang kiai dengan ciri-ciri khas yang bersifat karismatik serta independen dalam segala hal" (Rahardjo, 1985: 99). Atau dengan kata lain, pesantren merupakan lembaga pendidikan yang terdiri dari elemen-elemen khas yang dirumuskan oleh Dhofier sebagai berikut; pondok, masjid, santri, pengajaran kitab-kitab Islam klasik dan kyai (Dhofier, 1982: 44).

Pondok merupakan tempat penginapan santri yang belajar di pesantren untuk memperlancar proses belajarnya dan menjalin hubungan guru-murid secara lebih akrab (Qomar, 2007: 1). Santri merupakan murid yang belajar agama Islam. 
Sedangkan kiai merupakan gelar yang diberikan oleh masyarakat kepada ahli agama Islam yang memiliki atau menjadi pimpinan pesantren dan mengajar kitab-kitab Islam klasik kepada santrinya (Dhofier, 1982: 55). Dalam proses pembelajaran yang berlangsung antara kiai dan santri, kitab kuning menjadi referensi wajib pesantren. Kitab kuning adalah kitab Islam klasik yang disusun para sarjana Islam abad pertengahan (Rahardjo, 1985: 55).

Pesantren sebagai sebuah lembaga pendidikan memiliki sistem pendidikan khas pesantren. Sistem pendidikan pesantren (Qomar, 2007: 51) terdiri dari:

\section{Nilai dasar pesantren.}

Sebagai lembaga keagamaan dan pendidikan, pesantren mempunyai nilai dasar yang menjadi semangat perjuangannya. Nilai dasar yang hidup di dalam dunia pesantren adalah seluruh kehidupan di dunia ini diyakini sebagai ibadah kepada Allah SWT (A'la, 2006: 4). Pemeliharaan nilai dasar pesantren ditekankan pada fungsi mengutamakan beribadah sebagai pengabdian termasuk pada penyelenggaraan pendidikan (Wahid, 2010: 72). Nilai dasar ini kemudian membentuk sebuah sistem nilai yang dikenal dengan Ahl-al-Sunnah wa-al-Jama'ah (Madjid, 1997: 31).

\section{Pondok (asrama)}

Pondok atau asrama adalah ciri khas tradisi pesantren yang merupakan tempat tinggal santri. Pesantren pada dasarnya adalah sebuah pendidikan Islam tradisional yang menempatkan para santri untuk tinggal bersama ke dalam sebuah asrama atau pondokan untuk belajar melalui bimbingan kiai (Dhofier, 1982: 44).

\section{Kurikulum}

Abdurrahman Wahid (2010:151) menyebutkan tiga jenis kurikulum yang ada di pesantren, (1) kurikulum pengajian nonsekolah, kurikulum yang memiliki jenjangnya sendiri, bersifat sangat fleksibel karena bersifat individual oleh masingmasing santri, (2) kurikulum sekolah tradisional (madrasah salafiah), yakni sistem kelas yang kurikulumnya masih didasarkan pada penahapan dan penjenjangan berdasarkan urutan-urutan teks kuno secara berantai, (3) pondok modern, di mana kurikulumnya telah bersifat klasikal dan masing-masing kelompok agama dan nonagama telah menjadi bagian integral dari sebuah sistem yang telah bulat dan berimbang. 
Qomar (2007: 111) merangkum muatan kurikulum yang ada di pesantren meliputi: "Al-Quran dengan tajwid dan tafsirnya, aqaid dan ilmu kalam, fiqh dengan ushul fiqh dan qawaid al-fiqh, hadist dengan mushthalah Hadis, bahasa Arab dengan ilmu alatnya seperti nahwu, sharaf, bayan, ma'ani, badi' dan 'arudh, tarikh, mantiq, tasawuf, akhlak dan falak". Kurikulum ini merupakan kurikulum yang masih dipertahankan oleh pondok pesantren salafi.Sedangkan pondok pesantren khalafi, kurikulumnya mengadaptasi dari kurikulum pendidikan Islam yang dirancang oleh Departemen Agama dalam sekolah formal yang berupa madrasah serta kurikulum pesantren secara lokal menurut ciri khas pesantren itu sendiri (Assegaf, 2003: 298).

Konsekuensi dari perbedaan kurikulum tersebut berdampak terhadap sumber belajar yang digunakan antara pesantren salafi dan pesantren khalafi. Sumber belajar utama pesantren salafi adalah kitab Islam klasik (al-kutub al-qadimah) atau kitab kuning (Nata, 2001: 165). Sedangkan sumber belajar yang digunakan pesantren khalafi lebih bervariatif. Selain kitab kuning, pesantren khalafi juga menggunakan kitab modern (al-kutub al-'asyriyah) dan buku-buku kontemporer sebagai sumber belajarnya (Qomar, 2007: 129), mengingat bidang keilmuan yang dipelajari di pesantren khalafi tidak hanya ilmu agama melainkan juga ilmu umum. Bahkan beberapa pesantren khalafi sudah tidak menggunakan kitab kuning (Dhofier, 1982:43).

\section{Metode pembelajaran}

Metode pembelajaran yang digunakan di pesantren adalah sorogan, bandongan (wetonan/halaqah) dan hafalan (Nata, 2001: 107). Metode sorogan adalah metode pembelajaran secara individual dimana santri menghadap kiai seorang demi seorang untuk membacakan suatu kitab, sedangkan kiai atau ustadz mendengarkan dan mengkoreksi jika ada kesalahan dari bacaan santri tersebut (Ismail,2002: 67).

Metode bandongan adalah metode pembelajaran secara kolektif dimana santri mengikuti pelajaran dengan mendengarkan seorang kiai atau ustadz yang membaca, menerjemahkan, menerangkan dan mengulas kitab Islam dalam bahasa Arab. Setiap santri menyimak dan memperhatikan kitabnya masing-masing dan membuat catatan untuk kata-kata dan buah pikiran yang sulit (Dhofier, 1982: 28). Metode hafalan 
adalah metode pembelajaran dimana santri menghafal teks atau kalimat tertentu baik dari Al-Qur'an, hadis maupun kitab yang sedang dipelajarinya.Isi kitab yang dihafal biasanya berupa syair atau nazham (Nata, 2001: 108).

Dalam perkembangannya, pesantren juga menggunakan metode klasikal, muhawarah, mudzakarah, musyawarah, seminar, dan diskusi (Qomar, 2007: 149). Metode klasikal yaitu santri mengikuti pelajaran dengan duduk di sekeliling kiai yang menerangkan pelajaran secara kuliah dan terjadwal (Ismail, 2002: 101). Metode muhawarah merupakan suatu kegiatan berlatih bercakap-cakap dengan bahasa Arab (Qomar, 2007: 146). Metode mudzakarah merupakan suatu pertemuan ilmiah yang secara spesifik membahas masalah diniyyah seperti aqidah, ibadah, dan masalah agama pada umumnya (Qomar, 2007: 146). Metode musyawarah merupakan kegiatan diskusi mengenai pelajaran yang sudah dan yang akan dipelajari (Daulay, 2009: 70). Metode seminar merupakan metode pembelajaran dengan menghadirkan narasumber yang membahas suatu materi tertentu (Qomar, 2007: 153). Metode diskusi merupakan metode andalan proses belajar-mengajar di perguruan tinggi yang membuka kesempatan munculnya pemikiran liberal dengan dasar argumentasi ilmiah (Qomar, 2007: 152).

\section{Metode Penelitian}

Penelitian ini menggunakan metode penelitian kualitatif. Menurut Bogdan dan Taylor, penelitian kualitatif sebagai prosedur penelitian yang menghasilkan data deskriptif berupa kata-kata tertulis atau lisan dari orang-orang atau perilaku yang diamati (Moleong, 2004: 14). Penelitian ini dilakukan di Komplek R2 Pondok Pesantren Al-Munawwir Krapyak yang secara administratif berada di Dusun Krapyak Kulon, Desa Panggungharjo, Kecamatan Sewon, Kabupaten Bantul, Provinsi Daerah Istimewa Yogyakarta.

Untuk mendapatkan data yang akurat, penelitian ini menggunakan teknik pengumpulan data dengan cara observasi, wawancara, studi dokumentasi dan studi kepustakaan. Observasi dalam penelitian ini dilakukan di lingkungan Pondok Pesantren Al-Munawwir, khususnya Komplek R2. Wawancara dilakukan terhadap beberapa informan kunci yang mengetahui kondisi pesantren. Studi dokumentasi 
yaitu mempelajari dokumen-dokumen yang ditemukan di lapangan sebagai pelengkap dalam pengumpulan data.Studi kepustakaan yakni menelaah berbagai macam pustaka yang relevan terutama berkenaan dengan konsep-konsep pendidikan pesantren.

Dalam penelitian ini teknik analisis data menggunakan model Miles dan Huberman, dimana aktivitas dalam analisis data kualitatif dilakukan secara interaktif dan berlangsung secara terus-menerus sampai tuntas, sehingga datanya sudah jenuh. Aktivitas dalam analisis data, yaitu data reduction, data display, dan conclusion drawing/verification (Sugiyono, 2010: 246).

\section{Hasil Penelitian}

\section{Nilai Dasar Komplek R2}

Komplek R2 sebagai lembaga pendidikan model pesantren masih memegang teguh nilai dasar pesantren yakni semua hal yang dilakukan dilandasi sebagai bagian dari ibadah kepada Allah SWT. Nilai ini menjadi dasar penyelenggaraan pendidikan yang dilakukan oleh pengasuh dan ustadz.Nilai ibadah yang diyakini oleh ustadz sebagai bagian dari nilai dasar yang dianut komunitas pesantren dijadikan pijakan dalam mengajar santriwati di pesantren. Nilai dasar ini juga dijadikan pijakan pengasuh dalam mendirikan Komplek R2.

Sebagai realisasi dari nilai ibadah yang dianut oleh pengasuh dan ustadz, maka Ny. Hj. Ida Fatimah selaku pengasuh Komplek R2 mendirikan pesantren yang diberi nama Komplek R2. Komplek R2 didirikan sebagai bentuk cita-cita dari pengasuh untuk menyelenggarakan pendidikan agama Islam sesuai tradisi kepesantrenan yang mengenal dua ciri khas elemen pesantren yaitu lembaga pendidikan dengan pengajian kitab kuning dan penggunaan sistem asrama.

Penyelenggaraan pendidikan agama Islam di Komplek R2 sesuai dengan tradisi pesantren yang menggunakan kitab kuning sebagai sumber belajar. Kitab kuning adalah kitab Islam klasik atau kutub al-salafi yang telah diakui oleh banyak ulama sebagai referensi keilmuan. Berbeda dengan kajian di luar pesantren yang menggunakan buku-buku kontemporer hasil terjemahan, kajian Islam di pesantren 
menggunakan sumber keilmuan berupa kitab Islam klasik sehingga santriwati mendapat sumber referensi yang diakui oleh ulama.

Penyelenggaraan pendidikan yang masih menggunakan kitab kuning merupakan realisasi dari sistem nilai yang masih dianut Komplek R2, yaitu Ahl alSunnah wa al-Jama'ah. Penyelenggaraan pendidikan Islam di Komplek R2 juga sesuai dengan tradisi pesantren yang menggunakan sistem asrama sebagai tempat tinggal santriwati. Pesantren dengan sistem asrama ini didirikan sebagai jawaban dari permintaan beberapa orang tua santri kepada pengasuh untuk mendirikan pendidikan pesantren alternatif yang menyediakan fasilitas dan kesempatan kepada santriwatinya untuk belajar agama sekaligus menimba ilmu di luar pesantren.

Nilai dasar pesantren selain dijadikan landasan bagi pengasuh untuk mendirikan pendidikan agama Islam sesuai dengan tradisi pesantren yang menggunakan kitab kuning sebagai sumber belajarnya dan bersistem asrama, juga dijadikan landasan bagi Komplek R2 dalam menerima calon santriwati. Seperti yang digambarkan Soemardjan mengenai keunikan pesantren sebagai sebuah lembaga pendidikan yang terbuka bagi siapapun, Komplek R2 menerima semua calon santriwati dari berbagai kalangan.Dengan nilai dasar pengadaan pendidikan sematamata untuk beribadah, Komplek R2 berkomitmen untuk menerima semua santriwati yang ingin belajar tentang agama Islam. Komplek R2 tidak pernah menolak santiwati yang akan belajar.

Penghargaan yang tinggi terhadap keinginan belajar dari santriwati direalisasikan oleh Komplek R2 dengan menerima semua calon santriwati yang ingin belajar. Bagi Komplek R2, tidak ada kriteria ataupun kemampuan khusus yang harus dimiliki calon santriwati. Semua calon santriwati yang ingin belajar dipersilahkan menjadi santriwati Komplek R2.Adanya keterbatasan ruang bagi santriwati yang ingin mondok tidak membuat Komplek R2 menolak keinginan santriwati dalam hal mencari ilmu. Santriwati yang tidak tertampung di asrama tetap bisa mengikuti pendidikan di Komplek R2 meskipun tidak mendiami asrama.

Pendidikan yang dibangun di komplek R2 menerima semua santriwati tanpa memberikan kriteria-kriteria tertentu telah sesuai dengan cita-cita yang dikemukakan Illich mengenai sebuah lembaga pendidikan yang seharusnya menyediakan sumber 
daya bagi siapapun yang ingin belajar. Pendidikan yang dibangun di Komplek R2 menyediakan kesempatan bagi siapapun yang ingin belajar dengan menerima semua calon santriwati tanpa kriteria apapun.

\section{Pondok (Asrama) Sebagai Model Pendidikan Alternatif}

Pendidikan alternatif merupakan pendidikan dengan pendekatan yang bersifat individual. Dengan pendekatan yang bersifat individual memungkinkan pendidik untuk memberikan perhatian yang lebih besar kepada murid maupun kepada orang tua murid (Miarso, tt: 1). Menurut Ki Hajar Dewantara, pendidikan yang memberikan perhatian lebih besar kepada murid bisa direalisasikan salah satunya dengan sistem asrama (Saksono, 2008: 55).

Selajan dengan konsep pendidikan alternatif, Komplek R2 menjalankan model pendidikannya dengan sistem asrama atau pondok dalam istilah pesantren. Mondok adalah istilah bagi santriwati yang hidup dan bertempat tinggal di asrama pesantren.Asrama merupakan ruang di mana interaksi antara pengasuh dan santriwati berlangsung sebagai sebuah keluarga besar. Kehidupan di Komplek R2 seperti kehidupan di dalam sebuah keluarga dengan adanya pengasuh yang berperan sebagai orang tua yang memberikan nasehat, teladan dan doa kepada santriwati yang sudah dianggap seperti anak sendiri.

Sistem asrama memberikan kesempatan yang lebih banyak bagi pengasuh untuk memberikan perhatian dan bimbingan kepada santriwati. Sistem asrama juga memberikan kesempatan kepada santriwati untuk merasakan suasana kekeluargaan yang didapatkan dari perhatian pengasuh dan interaksinya dengan sesama santriwati lain.Sistem asrama yang diterapkan di Komplek R2 memberikan kesempatan kepada pengasuh (among) dan santriwati bertempat tinggal di lingkungan yang sama menjadi sebuah keluarga yang besar.

\section{Kurikulum Berbasis Integrasi Keilmuan}

a. Penghargaan Terhadap Karakteristik Santriwati

Kurikulum yang diterapkan di komplek R2 adalah kurikulum berbasis integrasi keilmuan (knowledge-integrated/ittihad al-ulum wa al-ma'rifah). 
Kurikulum berbasis integrasi keilmuan adalah kurikulum yang memadukan antara materi-materi keagamaan dengan materi non-keagamaan yang didasarkan pada karakteristik santriwati.

Kurikulum berbasis integrasi keilmuan disusun oleh Dewan Pembina dan Pengasuh Komplek R2 karena dilatarbelakangi perbedaan karakteristik santriwati. Sedikitnya ada tiga latar belakang yang membedakan santriwati sehingga melahirkan kurikulum yang integrated. Pertama, santriwati yang mayoritas mahasiswa dengan latar belakang keilmuan yang berbeda. Kedua, santriwati pelajar. Ketiga, santriwati yang sudah lulus pendidikan formal tetapi belum masuk perguruan tinggi.

Ketiga perbedaan latar belakang di atas menujukkan adanya tingkat intelektualitas santriwati yang multidisplin. Perbedaan tersebut kemudian diadaptasikan dengan kurikulum pesantren yang dielaborasi dengan keilmuan yang dipelajari santriwati di perguruan tinggi dan sekolah formal sehingga melahirkan kurikulum yang terintegrasi.

Kurikulum komplek R2 yang berbasis integrasi keilmuan memberikan penghargaan terhadap keberagaman karakteristik santriwati karena disesuaikan dengan kemampuan dan kebutuhan santriwati. Penghargaan terhadap karakteristik santriwati ini sejalan dengan hakikat pendidikan alternatif yang memberikan pendidikan sesuai dengan perbedaan minat, kebutuhan, kemampuan dan kondisi manusia yang bersangkutan.Dengan mempertimbangkan keberagaman karakteristik santriwati, Komplek R2 telah menerapkan pendidikan alternatif dalam kurikulumnya.

\section{b. Materi Keilmuan yang Integratif}

Kurikulum pesantren adalah seperangkat rencana (planning) dan pengaturan yang digunakan dalam penyelenggaraan proses belajar mengajar yang mencakup materi studi dan mata pelajaran.Dewan Pembina Madrasah Salafiyah V Komplek R2 merancang kurikulum berbasis integrasi keilmuan yang memadukan antara materimateri keagamaan dengan materi non-keagamaan yang didasarkan pada karakteristik santriwati. 
Kurikulum berbasis integrasi keilmuan yang diterapkan di Komplek R2 merupakan implementasi dari pandangan pengasuh Pondok Pesantren Al-Munawwir, K.H. Zainal Abidin Munawwir mengenai hakikat keilmuan. Hakikatnya, semua ilmu adalah milik Allah sehingga tidak ada dikotomi antara ilmu agama dan ilmu non agama atau ilmu umum. Perbedaan antara ilmu satu dengan yang lainnya menurut pengasuh terbagi menjadi tiga kategori berdasarkan wilayah kajiannya, yaitu: al'Ulum al-Syari'iyyah, al-'Ulum al-Lisaaniyyah dan al-'Ulum al-Kauniyyah (Fattah, 2014: 15).

Kurikulum berbasis integrasi keilmuan Komplek R2 meliputi materi bidang studi akidah (tauhid), Al-Quran, Hadis, akhlak (tasawuf), fiqih, fiqih mar'ah (fiqih wanita), nahwu (sintaksis), sharaf (morfologi), ulum-al-Quran (ilmu-ilmu Al-Quran), ulum-al-Hadis (ilmu-ilmu Hadis), bahasa Arab, bahasa Inggris, ush-ul-fiqih (metode penggalian hukum Islam), kajian teologi (ahl-al-sunnah wal-jama'ah), tafsir AlQuran dan bahts-al-masa'il (diskusi kajian aktual kontemporer) serta materi-materi yang disesuaikan kebutuhan santriwati.Pemberian materi bidang studi pesantren salafi seperti tauhid, Al-Quran, Hadis, akhlak, fiqih, nahwu, sharaf, ulum-al-Quran, ulum-al-Hadis, dan sebagainya dikarenakan pengasuh Komplek R2 ingin tetap mempertahankan tradisi keilmuan pesantren, terutama pesantren salafi.

Sedangkan kurikulum pesantren khalafi diterapkan di Komplek R2 dengan memasukkan bahasa Inggris sebagai materi keilmuannya. Bahasa inggris diajarkan di Komplek R2 sebagai upaya dari pengasuh untuk membekali santriwatinya agar dapat menguasai bahasa Internasional dan berkomunikasi dimana pun santriwati berada.Selain bahasa Inggris, Komplek R2 juga menyelenggarakan kajian aktual kontemporer yang dinamakan bahts-al-masail. Bahts-al-masail merupakan forum kajian fiqih yang diterapkan terhadap konteks kekinian. Forum ini diikuti oleh halaqah tsalisah dan halaqah rabiah dengan metode sorogan dan diskusi. Beberapa teks dalam kitab kuning dibaca dan diterjemahkan oleh santriwati di depan santriwati yang lain dan ustadz, kemudian diambil beberapa contoh kasus untuk didiskusikan bersama.

Dan terakhir dari muatan kurikulum pesantren khalafi yang diterapkan oleh Komplek R2 adalah kuliah umum dengan metode seminar dan diskusi yang 
menghadirkan narasumber dari perguruan tinggi yang memiliki background pesantren maupun narasumber yang berkompeten di bidangnya masing-masing. Kuliah umum mengangkat materi kajian aktual kontemporer yang diintegrasikan dengan nilai pesantren. Pembahasannya meliputi berbagai bidang keilmuan.

Keberagaman kurikulum di Komplek R2 melahirkan kurikulum yang integratif.Yang pertama, kurikulum Komplek R2 tidak hanya mengkaji keilmuan agama saja tetapi juga mengkaji keilmuan umum, karena hakikatnya semua ilmu milik Allah. Yang kedua, kurikulum Komplek R2 tidak hanya mempertahankan tradisi keilmuan pesantren salafi sebagai ciri khas pesantren tetapi juga memasukkan keilmuan yang terdapat di pesantren khalafi sebagai jawaban dari tantangan zaman. Yang ketiga, kurikulum Komplek R2 tidak hanya memuat materi keilmuan yang menambah wawasan intelektual santriwati saja tetapi juga memuat materi keilmuan yang bersifat membina akhlak, moral dan karakter santriwati.

\section{c. Sumber Belajar yang Berciri Salafi-Khalafi}

Kitab kuning atau kitab Islam klasik merupakan sumber belajar utama di pesantren, terutama pesantren salafi. Kitab kuning yang digunakan di pesantrenpesantren di Indonesia sebenarnya sangat beragam.Sedangkan sumber belajar yang digunakan oleh pesantren khalafi adalah kitab modern dan buku kontemporer yang banyak menggunakan metode penulisan dan analisis Barat. Berikut ini adalah daftar sumber belajar yang digunakan di Komplek R2 sesuai dengan ciri khas pesantren salafi maupun khalafi.

Tabel 1. Ciri Pesantren

\begin{tabular}{|c|l|}
\hline Ciri Pesantren & \multicolumn{1}{|c|}{ Sumber Belajar } \\
\hline \multirow{5}{*}{ Salafi } & $\begin{array}{l}\text { Matan al-Jurumiyyah, Imrithy (Nahwu); Matan al-Ghayah wa Taqrib , } \\
\text { Fath al-Qorib; Fath al-Mu'in(Fiqih); Durus al-Aqoid al-Diniyah (Tauhid); } \\
\text { al-Waraqat, Al-Qawa'id fi Ush al-Fiqh (Ushul Fiqih); Ayat al-Ahkam min } \\
\text { al-Quran(Tafsir); Qowa'id fi ulum al-quran(ilmu Quran); Minhah al- } \\
\text { Mughits (ilmu Hadis); Izzah al-Nasyi'in, Bidayah al-Hidayah, Kifayah al- } \\
\text { Atqiyah(Akhlak) }\end{array}$ \\
\hline Khalafi & $\begin{array}{l}\text { al-Arabiyah li al-Nasyi'in (Bahasa Arab), English for Student } \\
\text { (Bahasa Inggris), Beberapa Artikel dan modul dari Ustadz untuk } \\
\text { kuliah Umum }\end{array}$ \\
\hline \multirow{3}{*}{ Salafi-Khalafi } & $\begin{array}{l}\text { Ahl al-Sunnah wa al-Jama'ah (Teologi), Al-Muqtathafat (Hadis), } \\
\text { Wazaif al-Muta'alim (Akhlak), Al-Furuq (Fiqih Perbedaan), Sharaf } \\
\text { Praktis Metode Krapyak(Sharaf) }\end{array}$ \\
\hline
\end{tabular}

Sumber: Dokumen pengurus Madrasah Salafiyah V Komplek R2. 
Dari tabel 1 dapat dilihat bahwa Komplek R2 masih mempertahankan ciri pesantren salafi dengan menggunakan berbagai kitab kuning sebagai sumber belajarnya. Kitab kuning yang digunakan juga merupakan kitab kuning yang lazim dipelajari di pesantren-pesantren yang lain.Sedangkan ciri pesantren khalafi dapat dilihat dari penggunaan buku kontemporer untuk pelajaran bahasa Arab dan bahas Inggris. Selain itu juga terdapat modul dan artikel yang disusun ustadz dari berbagai sumber referensi sebagai sumber belajarnya. Penyusunan modul dan artikel merupakan usaha ustadz untuk membantu santriwati dalam mendapatkan isu dan wacana aktual dengan konteks kekinian.Kemudian yang menjadi menarik adalah penggunaan sumber belajar berupa kitab-kitab yang disusun atau dikarang sendiri oleh pengasuh maupun ustadz yang berciri pesantren salafi dan khalafi.

\section{Metode Pembelajaran Gabungan Salafi-Khalafi}

\section{a. Sistem Klasikal Berdasarkan Kemampuan Santriwati}

Komplek R2 menerapkan metode pembelajaran dengan sistem klasikal yang dinamakan Madrasah Salafiyah V. Model pembelajaran dengan sistem klasikal yang diterapkan di Komplek R2 membagi jenjang pendidikan menjadi empat kelas yang ditempuh selama empat tahun. Pembagian jenjang yang ditempuh selama empat tahun dilatarbelakangi masa studi santriwati Komplek R2 di perguruan tinggi yang diasumsikan ditempuh selama empat tahun.

Dalam prakteknya, masa studi santriwati di Komplek R2 bisa kurang dari empat tahun maupun lebih dari empat tahun. Masa studi santriwati disesuaikan juga berdasarkan kemampuan santriwati untuk menguasai materi-materi keilmuan yang telah disusun di dalam kurikulum pesantren.Kemampuan santriwati untuk menangkap pelajaran tentu berbeda-beda. Terlebih lagi latar belakang santriwati yang bervariasi, ada yang sebelumnya sudah pernah belajar di pesantren lain. Ada juga santriwati yang ketika masuk komplek R2 sama sekali belum memiliki pengalaman mondok di mana pun.

| Volume. 2, No. 1, Januari-Juni 2017 
Berbeda dengan sistem sekolah formal yang membagi jenjang pendidikannya berdasarkan umur, pembagian kelas di Komplek R2 berdasarkan kemampuan santriwati dalam menerima dan menguasai pelajaran. Jika ada santriwati yang dirasa sudah menguasai materi pelajaran, santriwati tersebut berhak ditempatkan di kelas yang lebih tinggi. Tetapi jika santriwati merasa kurang bisa mengikuti pelajaran, santriwati tersebut ditempatkan di kelas yang sesuai dengan kemampuannya.

Adanya sistem klasikal dengan pembagian jenjang pedidikan berdasarkan kemampuan santriwati dalam menguasai materi pelajaran yang diterapkan di Komplek R2 memberikan kesempatan kepada santriwati untuk belajar sesuai dengan kemampuannya. Sistem klasikal yang diterapkan di komplek R2 ini sesuai dengan hakikat pendidikan yang diajarkan oleh Ki Hajar Dewantara bahwa pendidikan merupakan upaya memanusiakan manusia secara manusiawi dan dilakukan sesuai dengan kodrat alam. Memaksakan pendidikan tidak sesuai dengan kemampuan masing-masing santriwati merupakan pengingkaran terhadap kodrat alam manusia. Dengan menghargai setiap kemampuan yang dimiliki santriwati, Komplek R2 berusaha mengadakan pendidikan yang memanusiakan manusia secara manusiawi sesuai dengan kodrat alamnya.

\section{b. Sorogan, Pendekatan yang Bersifat Individual}

Penggunaan metode sorogan memberikan kesempatan kepada ustadz untuk memberi perhatian yang lebih besar terhadap perkembangan santriwati. Kemampuan membaca, mengartikan dan menjelaskan bacaan yang dilakukan setiap santriwati dapat dipantau dan diperhatikan oleh ustadz dengan menggunakan metode sorogan.Sorogan tetap dipertahankan sebagai metode pembelajaran karena merupakan metode pembelajaran yang khas pesantren, terutama pesantren salafi. Sistem sorogan memiliki kelebihan karena sistem ini menuntut santriwati untuk aktif belajar mandiri, memaknai atau mengartikan sendiri sumber belajar berupa kitab dengan bahasa Arab, mencari struktur bahasa dengan kaidah nahwu dan sharaf, serta melatih santriwati memahami konteks bacaan. Metode ini menuntut santriwati untuk mencari tahu sumber ilmu secara mandiri yang pada akhirnya membuka wawasan dan pola pikir santriwati. 
Metode sorogan dengan pendekatan yang bersifat individual diterapkan Komplek R2 sejalan dengan konsep pendidikan yang diajarkan Freire. Metode sorogan merupakan implementasi dari problem posing education dimana santriwati dibiasakan mencari tahu sendiri mengenai keilmuan yang digali dari sumber belajar. Setelah memahami makna dan konteks dari sumber belajar, santriwati diajak berdiskusi dengan ustadz untuk menjelaskan apa yang sudah di dapatkan dari sumber belajar. Ustadz dan santriwati sama-sama menjadi subyek belajar.

\section{c. Ceramah Sebagai Metode yang Efektif dan Efisien}

Selain sistem klasikal dan sorogan, Komplek R2 juga menggunakan metode ceramah sebagai metode pembelajarannya. Metode ceramah digunakan pada waktu kuliah umum yang dilaksanakan setiap satu bulan sekali. Penggunaan metode ceramah dikarenakan metode ini efisien ketika digunakan untuk menghadapi jumlah santriwati yang mencapai puluhan orang. Metode ceramah dan diskusi juga membuat proses belajar menjadi lebih efektif dan tepat sasaran. Selain itu penggunaan metode ceramah mempermudah ustadz mencapai arah dan tujuan pembelajaran.

Kuliah umum wajib diikuti oleh seluruh santriwati. Berbeda dengan model klasikal yang membedakan santriwati berdasarkan kemampuan penguasaan materi dengan penjenjangan kelas. Kuliah umum tidak melihat batasan kemampuan penguasaan materi santriwati. Hal ini karena materi yang disampaikan di kuliah umum merupakan materi pengayaan yang diharapkan dapat memperkaya wawasan santriwati.

Adanya kuliah umum setiap satu bulan sekali menambah wawasan santriwati terhadap penguasaan keilmuannya. Santriwati tidak hanya diajarkan mengenai ajaran Islam yang bersumber dari kitab kuning tetapi juga ceramah dan diskusi yang membahas mengenai berbagai materi umum. Dengan metode ceramah, semua santriwati mempunyai kesempatan untuk mendapatkan wawasan keilmuan yang tidak terbatas dari materi-materi umum. Dengan metode ceramah, penyampaian materi menjadi lebih efektif dan efisien. 


\section{Kesimpulan}

Salah satu pesantren yang membangun model pendidikan pesantren alternatif adalah Komplek R2 Pondok Pesantren Al-Munawwir Krapyak Yogyakarta. Model pesantren salafi-khalafi yang dibangun di Komplek R2 merupakan gabungan dari model salafi dan model khalafi. Model pesantren salafi-khalafi sebagai pendidikan alternatif bisa dilihat dari sistem pendidikan pesantren yang terdiri dari empat aspek: nilai dasar pesantren, pondok (asrama), kurikulum dan metode pembelajaran yang digunakan.

Pendidikan yang dibangun di Komplek R2 menjadi pilihan alternatif bagi masyarakat yang ingin mendapatkan pendidikan dengan tradisi pesantren salafi sekaligus tradisi pesantren khalafi. Komplek R2 menjadi pilihan alternatif bagi masyarakat yang mendambakan pendidikan yang tidak membeda-bedakan kemampuan individu—pendidikan yang menyediakan kesempatan yang sama bagi setiap orang untuk mencari ilmu. Komplek R2 juga menjadi pilihan alternatif bagi masyarakat tidak hanya haus akan pendidikan yang menambah wawasan intelektual saja tetapi juga pendidikan yang mengembangkan akhlak, karakter dan budi pekerti luhur.

\section{Daftar Pustaka}

Assegaf, Abdur Rachman. 2003. Internasionalisasi Pendidikan. Yogyakarta: Gama Media.

Azra, Azyumardi. 2002. Paradigma Baru Pendidikan Nasional. Jakarta: Kompas.

A’la, Abd. 2006. Pembaruan Pesantren. Yogyakarta: Pustaka Pesantren.

Daulay, Haidar Putra. 2009. Sejarah Pertumbuhan dan Pembaruan Pendidikan Islam di Indonesia. Jakarta: Kencana.

Dhofier, Zamakhsyari. 1982. Tradisi Pesantren: Studi Tentang Pandangan Hidup Kiai. Jakarta: LP3ES.

Fatah, Munawwir Abdul. 2014. Lembaga Pendidikan Al-Quran Ideal. Majalah Almunawwir. Edisi V/2014. Yogyakarta: Pondok Pesantren Al-Munawwir.

Freire, Paulo. 2002. Politik Pendidikan: Kebudayaan, Kekuasaan dan Pembebasan, terj. Agung Prihantoro, Fuad Arif Fudiyartanto. Yogyakarta: Pustaka Pelajar. 
Ismail SM, dkk., (ed.). 2002. Dinamika Pesantren dan Madrasah. Yogyakarta: Pustaka Pelajar.

Knight, George R. 2007.Filsafat Pendidikan, terj. Mahmud Arif. Yogyakarta: Gama Media.

Madjid, Nurcholish. 1997. Bilik-bilik Pesantren Sebuah Potret Perjalanan. Jakarta: Paramadina. . 1993. Islam Kerakyatan dan Keindonesiaan. Bandung: Mizan.

Miarso, Yusufhadi. t.th. Pendidikan Alternatif, Sebuah Agenda Reformasi. Jakarta: Jurusan Teknologi Pendidikan Universitas Negeri Jakarta.

Moleong, Lexy J. 2004. Metode Kualitatif. Bandung: Remaja Rosdakarya.

Nata, Abuddin. 2001. Sejarah Pertumbuhan dan Perkembangan Lembaga-lembaga Pendidikan Islam di Indonesia. Jakarta: Grasindo.

Qomar, Mujamil. 2006. Pesantren: Dari Transformasi Metodologi Menuju Demokratisasi Institusi. Jakarta: Erlangga.

Rahardjo, M. Dawam (ed.). 1985. Pergulatan Dunia Pesantren Membangun dari Bawah. Jakarta: P3M.

Saksono, Ign. Gatut. 2008. Pendidikan yang Memerdekakan Siswa. Yogyakarta: Rumah Yabinkas.

Soemardjan, Selo. 2009. Perubahan Sosial di Yogyakarta. Jakarta: Komunitas Bambu.

Sugiyono. 2010. Metode Penelitian Kuantitatif, Kualitatif dan R\&D. Bandung: Alfabeta.

Tilaar, H.A.R. 2002.Pendidikan, Kebudayaan, dan Masyarakat Madani Indonesia. Bandung: Rosdakarya.

Wahid, Abdurrahman Wahid. 2010. Menggerakkan Tradisi. Yogyakarta: LKiS.

\section{Sumber Wawancara}

Wawancara mendalam dengan Ustadz Syarwani pada tanggal 6 September 2013 dan 10 Januari 2014. 
20 Lita Nala Fadhila

Pendidikan Alternatif dengan Model Pesantren Salafi-Khalafi (Studi Komplek R2

Pondok Pesantren Al Munawwir Krapyak Yogyakarta)

Wawancara mendalam dengan Ibu Ny. Hj. Ida Fatimah pada tanggal 4 September 2013. 